EKONOMI POLITIK INSTITUSI ZAKAT: SATU PENELITIAN TERHADAP INSTITUSI ZAKAT DI PULAU PINANG

Mohammad Najwa

PRAKTIK KURBAN ONLINE DALAM PERSPEKTIF ISLAM TEBAR HEWAN KURBAN THK DI DOMPET DHUAFA

Reni Noviati

WAKAF SAHAM DITINJAU DARI HUKUM ISLAM DAN PERATURAN PERUNDANGUNDANGAN SETELAH BERLAKUNYA UNDANG-UNDANG NOMOR 41

TAHUN 2004 TENTANG WAKAF

Gusva Havita dan Gestivia Hakim

KARAKTERISTIK ENTREPRENEUR SYARIAH PADA USAHA MIKRO, KECIL, DAN MENENGAH (UMKM) DI BOGOR

Siti Usniah dan Anas Alhifni

ALTERNATIF SOLUSI ATAS PROBLEMATIKA PEMBIAYAAN MUDHARABAH

Rafidah

FAKTOR-FAKTOR YANG MEMPENGARUHI MOTIVASI MAHASISWA MENJADI ENTREPRENEUR SYARIAH

Nur Maulida Hidayat dan Anas Alhifni 
Ketua Editor :

Tuti Kurnia, SP., M.Si

Editor Pelaksana :

H. Sofian Muhlisin, LLB., LLM

Furqonul Haq, SEI., M.EI

Journal Manager :

Wildan Munawar, SEI

Jurnal Syarikah: Jurnal Ekonomi Islam adalah jurnal ilmiah yang diterbitkan untuk mendukung pengembangan ekonomi Islam. Jurnal Syarikah akan memuat artikelartikel yang terkait dengan kajian ekonomi Islam baik kajian teoritis maupun praktis. Redaksi menerima sumbangan artikel, tulisan ilmiah dari para peminat ilmiah kajian ekonomi dan keuangan syariah. Proses editing seperlunya tanpa mengubah maksud dan kandungan tulisan tersebut.

Alamat Redaksi :

Fakultas Ekonomi Islam

Universitas Djuanda Bogor

Gedung B Lantai 4

Jl. Tol Ciawi No.1 Ciawi Bogor Kode Pos 16720

Telp. (0251) 8240985

Email : fei@unida.ac.id 


\section{DAFTAR ISI}

EKONOMI POLITIK INSTITUSI ZAKAT: SATU PENELITIAN TERHADAP INSTITUSI ZAKAT DI PULAU PINANG

Mohammad Najwa

PRAKTIK KURBAN ONLINE DALAM PERSPEKTIF ISLAM TEBAR HEWAN KURBAN THK DI DOMPET DHUAFA

Reni Noviati

WAKAF SAHAM DITINJAU DARI HUKUM ISLAM DAN PERATURAN PERUNDANG-UNDANGAN SETELAH BERLAKUNYA UNDANG-UNDANG NOMOR 41 TAHUN 2004 TENTANG WAKAF

Gusva Havita, Gestivia Hakim

KARAKTERISTIK ENTREPRENEUR SYARIAH PADA USAHA MIKRO, KECIL DAN MENENGAH (UMKM) DI BOGOR

Siti Usniah, Anas Alhifni

ALTERNATIF SOLUSI ATAS PROBLEMATIKA PEMBIAYAAN MUDHARABAH

Rafidah

FAKTOR-FAKTOR YANG MEMPENGARUHI MOTIVASI MAHASISWA MENJADI ENTREPRENEUR SYARIAH

Nur Maulida Hidayat, Anas Alhifni 


\title{
ALTERNATIF SOLUSI ATAS PROBLEMATIKA PEMBIAYAAN MUDHARABAH
}

\section{ALTERNATIVE SOLUTION TO THE PROBLEMATICS OF MUDHARABAH FINANCING}

\author{
Rafidah'1a; \\ 1a Universitas Islam Negeri Syarif Hidayatullah Jakarta, Jalan Ir. Haji Juanda No. 95, Ciputat, \\ Cempaka Putih, Ciputat Timur, Cemp. Putih, Ciputat Tim., Kota Tangerang Selatan, Banten \\ 15412
}

\begin{abstract}
Tujuan penelitian ini adalah untuk memberikan alternatif solusi atas problematika yang terjadi dalam pembiayaan mudharabah. Adapun metode penelitian yang digunakan adalah metode penelitian kualitatif dengan teknik analisis data menggunakan teknis deskriptif melalui pendekatan komparatif. Hasil penelitian menunjukkan bahwa terdapat beberapa hal yang yang bisa dilakukan untuk mengoptimalkan pembiayaan muḍārabah yakni melakukan screening terhadap pelaku proyek dan proyek yang akan dibiayai, melakukan analisis atas dokumen yang diajukan muḍārib, menawarkan suatu skema bagi hasil yang lebih menguntungkan bagi muḍārib dan menggunakan jaminan sebagai penjamin kepastian pelaku usaha agar tidak menyimpang dari ketentuan-ketentuan yang yang telah disepakati.

Kata kunci: Pembiayaan Mudharabah, Alternatif Solusi, Screening
\end{abstract}

\begin{abstract}
ABSTRAK
The purpose of this study is to provide an alternative solution to the problems that occur in mudharabah financing. The research method used is qualitative research methods with data analysis techniques using descriptive techniques through a comparative approach. The results show that there are several things that can be done to optimize the financing of muḍārabah by screening project actors and projects to be funded, analyzing the proposed documents muḍārib, offering a profit-sharing scheme that is more profitable for muribrib and using guarantees as guarantor The certainty of the business actor not to deviate from the agreed provisions.
\end{abstract}

Keywords: Mudharabah Financing, Alternative Solution, Screening

Rafidah. 2017. Alternatif Solusi Atas Problematika Pembiayaan Mudharabah. Jurnal Syarikah 3 (1): 391 - 402. 


\section{PENDAHULUAN}

Keberadaan bank syariah di Indonesia didirikan untuk menghindari permasalahan bunga yang terus menerus menjadi perdebatan panjang yang dikhawatirkan mengandung unsur riba. Oleh karena itu setiap aktivitas bank Syari'ah harus terhindar dari riba. Usaha menghindari kekhawatiran tersebut dilakukan antara lain dengan cara menerapkan bagi hasil.

Menurut Baiq perbankan syariah seharusnya mengembangkan dan meningkatkan pembiayaan dengan sistem bagi-hasil seperti mudārabah karena pembiayaan jenis ini memiliki beberapa dampak positif antara lain: akan menggairahkan sektor riil, rate of return bank syariah yang lebih tinggi dibanding dengan interest rate yang berlaku pada bank umum, akan mendorong tumbuhnya pengusaha/investor yang berani mengambil keputusan bisnis yang berisiko, dapat mengurangi peluang terjadinya resesi ekonomi dan krisis keuangan dan, sistem muḍārabah dan musyarakah dapat menjadi solusi alternatif atas problem overlikuiditas yang saat ini terjadi. (Baiq, 2006: 21)

Namun dalam dunia bank syariah praktik pembiayaan muḍārabah hingga saat ini belum menjadi primadona jenis pembiayaan, walaupun muḍārabah dikatakan sebagai sesuatu yang ideal untuk perbankan Islam. Di beberapa lembaga pembiayaan praktik pembiayaan akad ini merupakan praktik yang dihindari (Muhammad, 2011:303). Sehingga dengan demikian, penulis akan meneliti penyebab pembiayaan bagi hasil khususnya muḍārabah belum menjadi unggulan di perbankan syariah dan langkah-langkah apa yang mungkin dapat dilakukan untuk mendorong pembiayaan bagi hasil menjadi core bisnis perbankan syariah.

\section{MATERI DAN METODE}

\section{Pengertian Mudarabah}

Kata muḍ̄rabah berasal dari akar kata daraba pada kata al-ḍarb fi al-ardh, yakni bepergian untuk urusan dagang. Secara bahasa, menurut Abdurrahman al-Jaziri berarti ungkapan terhadap pemberian harta dari seseorang kepada orang lain sebagai modal usaha dimana keuntungan yang diperoleh akan dibagi di antara mereka berdua, dan bila rugi akan ditanggung oleh pemilik modal. (Sundjaja dan Barlian, 2002: 375)

Mudārabah adalah bentuk kerjasama khusus dimana seorang patner memberikan uang kepada patner lainnya untuk di investasikan ke dalam perusahaan komersial. Investasi yang berasal dari patner pertama di sebut "rabb-ul-mal", sementara manajemen dan pekerjaan adalah tanggung jawab patner yang lain dissebut "mudārib" (Kettel, 2008: 80). Disebut perjanjian kerjasama karena antar pemilik modal dan pelaku usaha merupakan pasangan (partner) yang secara langsung saling membutuhkan satu dengan yang lain. Pemilik modal secara langsung membutuhkan seorang pelaku usaha yangdapat menjalankan dana yang dimilikinya untuk suatu kegiatan usaha yangdapat menghasilkan keuntungan. Di lain pihak, pelaku usaha mempunyai keahlian, kesempatan dan kemampuan untuk melakukan usaha, secara langsung membutuhkan modal bagi usaha yang akan dilakukannya. Kepentingan saling membutuhkan secara langsung inilah yang diakomodasi dalam muḍarabah (Siddiqi, 1985: 14).

Fazlur Rahman mengatakan bahwa muḍārabah adalah kemitraan terbatas 
adalah perseroan antara tenaga dan harta, seorang (pihak pertama/supplier/pemilik modal/ shahibul maal) memberikan hartanya kepada pihak lain (pihak kedua/pemakai/pengelola/muḍārib) yang digunakan untuk bisnis, dengan ketentuan bahwa keuntungan (laba) yang diperoleh akan dibagi oleh masing-masing pihak sesuai dengan kesepakatan. Bila terjadi kerugian, maka ketentuannya berdasarkan syarat "bahwa kerugian dalam muḍarabah dibebankan kepada harta, tidak dibebankan sedikitpun kepada pengelola yang bekerja (Rahman, 1995: 24).

Dari pengertian diatas dapat diketahui bahwa muḍarabah adalah perjanjian atas suatu jenis kerja sama usaha di mana pihak pertama menyediakan dana (shahibul maal) dan pihak kedua (muḍārib) bertanggung jawab atas pengelolaan usaha. Keuntungan hasil usaha dibagikan sesuai dengan nisbah bagi hasil yang disepakati sejak awal. Akan tetapi, jika terjadi kerugian, shahibul maal akan kehilangan sebagian imbalan dari hasil kerjanya selama proyek berlangsung.

\section{Mekanisme Pembiayan Muḍārabah dalam Perbankan Syariah}

Pembiayaan muḍārabah dalam pelaksanaannya pada Bank Syariah adalah bank syariah bertindak sebagai (shahibulmal) yang menyediakan dana dengan fungsi sebagai modal kerja, dan nasabah bertindak sebagai pengelola dana (muḍārib) dalam kegiatan usahanya. Bank memiliki hak dalam pengawasan dan pembinaan usaha nasabah walaupun tidak ikut serta dalam pengelolaan usaha nasabah, anatara lain Bank dapat melakukan riview dan meminta bukti-bukti dari laporan hasil usaha nasabah berdasarkan bukti pendukung yang dapat dipertangungjawabkan (Wiroso 2011: 349).
Pembagian hasil usaha dari pengelolaan dana dinyatakan dalam nisbah yang disepakati atas dasar laporan hasil usaha pengelolaan dana (muḍārib) dengan disertai bukti pendukung yang dapat dipertanggung jawabkan. Apabila terjadi kerugian usaha nasabah pengelola dana (muḍārib) yang dapat ditanggung oleh bank selaku pemilik dana (shahibu al-maal) adalah maksimal sebesar jumlah pembiayaan yang diberikan (Wiroso 2011: 349).

Menurut Fatwa DSN No: 07/DSNMUI/IV/2000, tentang Pembiayaan Muḍārabah, pembiayaan muḍārabah adalah pembiayaan yang disalurkan oleh bank syariah kepada pihak lain untuk suatu usaha yang produktif. Dalam pembiayaan ini bank syariah sebagai shahibul maal (pemilik dana) menbiayai 100\% kebutuhan suatu proyek (usaha) sedangkan pengusaha (nasabah) bertindak sebagai muḍāib atau pengelola usaha (Fatwa DSN MUI, 2000: Pasal 1).

Mudārabah lebih cocok dan lebih praktis dalam perbankan Islam dibandingkan dengan syirkah. Secara teknis, muḍārabah muḍārabah adalah akad kerja sama usaha antra dua pihak, dimana pihak pertama (shahibu al-maal) menyediakan modal, sedangkan pihak lainnya menjadi pengelola. Syirkah hanya cocok untuk bank apabila bank tersebut berfungsi sebagai bank partisipan yang aktif dalam menjalankan bisnis. Muḍārabah bukan hanya cocok dengan bank syariah, namun fungsi pokok perbankan adalah memberikan modal kepada individu atau kelompok yang ingin berusaha, dan ini adalah muḍārabah (Rahman, 1995: 436).

\section{Metode Penelitian}

Penelitian ini menggunakan jenis penelitian kualitatif dengan metode deskriptif. Adapun sumber data yang 
digunakan adalah sumber data sekunder yang diperoleh dari hasil-hasil penelitian sebelumnya serta kajian pustaka yang berkaitan dengan problem pembiayaan mudharabah. Sedangkan analisis data menggunakan teknik deskriptif melalui pendekatan komparatif. Pendekatan komparatif ini digunakan untuk membandingkan hasil-hasil penelitian sebelumnya tentang problem pembiayaan mudharabah yang kemudian diberikan solusi alternatif atas setiap permasalahannya.

\section{HASIL DAN PEMBAHASAN}

\section{Risiko Pembiayaan Mudarabah}

pembiayaan muḍārabah adalah merupakan kerjasama usaha antara dua pihak/lebih dimana pihak pertama (sahhibul mal) menyediakan seluruh $(100 \%)$ dana kegiatan usaha sesuai kebutuhan pembiayaan kepada pengelola dana (muḍārib) untuk melaksanakan kegiatan tersebut.

Berdasarkan kegiatan tersebut mudārabah merupakan salah satu pembiayaan yang memiliki risiko cukup tinggi, diantaranya: side steaming dimana nasabah menggunakan dana itu bukan seperti yang disebut dalam kontrak, lalai dan kesalahan yang disengaja, penyembunyian keuntungan oleh nasabah bila nasabahnya tidak jujur (Rivai dan Veithzal, 2006: 430).

\section{Permasalahan Pembiayaan Mudarabah}

Rendahanya pembiayaan muḍārabah di perbankan syariah sampai saat ini masih menjadi persoalan penting dalam perbankan syariah. Karena pada dasarnya core value yang membedakan bank syariah dan bank konvensional adalah penggunaan sistem bagi hasil sebagai pengganti sistem bunga yang diterapkan pada pembiayaan mudāarabah maupun musyarakah.

Menurut para ahli lembaga keuangan syari'ah, permasalahan rendahnya pembiayaan bagi hasil disebabkan oleh beberapa faktor: (Yumanita, 2000: 23)

1. Internal

a. Kualitas Sumber Daya Insani (SDI) belum memadai untuk menangani proyek bagi hasil.

b. Lembaga Keuangan Syari'ah belum mampu menangani risiko besar.

c. Lembaga Keuangan Syari'ah terlalu mengutamakan orientasi bisnis dan keuntungan seperti institusi usaha pada umumnya.

d. Adverse selection, karena Asymetric Information antara kedua belah pihak.

e. Tidak adanya Personal Guarantee (seseorang yang dijadikan jaminan untuk pembiayaan. Jaminan dapat berupa nama besar, tokoh agama, dan lain-lain) dan Collateral (jaminan) pada nasabah.

f. Biaya informasi yang meningkat, terurtama untuk pembiayaan Muḍārabah.

g. Keterbatasan peran bank sebagai investor, terutama untuk pembiayaan Muḍārabah.

2. Eksternal

a. Sebagian nasabah sudah terbiasa dengan sistem bunga bank.

b. Moral hazard, karena pengusaha tidak mau menyampaikan laporan keuangan/keuntungan sebenarnya untuk menghindari pajak atau bagi hasil.

c. Permintaan pembiayaan bagi hasil yang masih kecil dari nasabah.

3. Regulasi

a. Kurangnya dukungan dari regulator, karena tidak melakukan inisiatifinisiatif untuk mengadakan perubahan 
peraturan dan institusional yang diperlukan untuk mendukung bekerjanya sistem perbankan syari'ah.

b. Tidak adanya prosedur operasional yang seragam antara lembaga keuangan syari'ah.

4. Pemerintah

a. Tidak ada kesepahaman dalam aturanaturan syari'ah dan proyek pendukung yang mendorong penggunaan bagi hasil untuk proyek-proyek pemerintah.

b. Pemberlakuan pajak yang tidak adil pada keuntungan sebagai objek pajak, sedangkan bunga bebas dari pajak.

c. Pasar sekunder instrumen keuangan syari'ah belum ada, sehingga bank kesulitan dalam menyalurkan atau mendapatkan akses likuiditas sesuai syari'ah.

d. Hak kepemilikan belum jelas, karena pembiayaan Profit Loss Sharing (Mudāarabah) memerlukan hak kepemilikan yang jelas dan berlaku efisien.

Rendahanya pembiayaan mudāarabah telah menjadi topik yang masih selalu dikaji oleh para akademi, mereka mendapatkan beberapa faktor yang yang menyebabkan rendahnya pembiayaan mudarabah di perbankan syariah. antara lain:

Muhammad mengatakan bahwa rendahnya pengguna produk pembiayaan yang berbasis sistem bagi hasil dikarenakan tingginya risiko yang dihadapi pihak perbankan, utamanya risiko yang berkaitan dengan masalah agency. Alasan ini muncul disebabkan oleh faktor eksternal bank, yaitu kondisi masyarakat pengguna jasa perbankan syariah untuk jenis muḍarabah. Artinya, keadaan tingkat kejujuran dan keamanahan masyarakat dalam menjalankan bisnis yang terkait dengan pembiayaan berbasis bagi hasil tersebut masih dirasa kurang (Muhammad, 2006: 3).
Kurniawati menyimpulkan bahwa di dalam kontrak muḍārabah sarat dengan munculnya Agency Problem. Agency problem berupa asymetrik informasi yang berupa moral hazard dan adverse selection (Kurniawati, 2008: 121). Prasetyo yang menyimpulkan bahwa masalah pokok yang mempengaruhi rendahnya minat pembiayaan Muḍārabah yaitu untuk masalah internal kurangnya pemahaman dan kualitas SDI Perbankan Syari'ah, dan untuk eksternalnya yaitu banyaknya moral hazard, serta kurangnya regulasi dari pemerintah yang mendukung. Pembiayaan produktif dengan akad muḍārabah memiliki risiko tinggi dengan akad-akad lainnya. Hal ini disebabkan tingkat pengembalian atau pendapatan yang akan diterima nantinya antara pihak Bank dan nasabah tidak pasti (Prasetyo, 2003: 14).

Maharani yang menguatkan adanya agency problem dalam kontrak Muḍārabah dengan kesimpulannya bahwa agency problem pada kontrak muḍārabah merupakan masalah krusial yang dihadapi oleh Bank Syari'ah (Maharani, 2008: 491). Zharfan menyimpulkan Pembiayaan Produktif dengan akad Muḍārabah pada PT. Bank BNI Syari'ah memiliki risiko yang tinggi dibandingkan dengan pembiayaan dengan akad-akad lainnya, seperti akad murābaḥah (jual-beli) dan akad musyārakah (kerjasama). Hal ini disebabkan karena permasalahan Principal-Agent, yaitu terjadinya asymmetric information dimana bank sebagai șāhịibul māl kurang mendapat informasi tentang keadaan usaha yang dibiayainya dibandingkan nasabah sebagai muḍārib yang lebih banyak mengetahui mengenai usaha yang dijalankannya. Permasalahan asymmetric information, baik adverse selection yaitu penilaian yang kurang tepat atas karakter nasabah dan moral hazard yaitu penyimpangan yang 
dilakukan nasabah, baik berupa level upaya yang tidak optimal atau pelaporan jumlah profit yang tidak benar oleh nasabah (Zharfan, 2012: 60).

Dari berbagai temuan diatas dapat disimpulkan bahwa permasalahan pokok yang sering terjadi dalam perbankan syariah sehingga menyebabkan rendahnya pembiayaan mudārabah adalah:

\section{Agency problem \\ 2. Adverse selection \\ 3. Moral hazard}

\section{Solusi Rendahnya Pembiayaan}

\section{Agency Problem}

Jensen dan Meckling dalam Maharani mendefinisikan agency theory adalah teori yang menjelaskan tentang hubungan antara principal dan agent dimana principal mendelegasikan wewenang kepada agent dalam hal pengelolaan usaha sekaligus pengambilan keputusan dalam perusahaan (Maharani, 2008: 495). Fokus teori keagenan mengatur hubungan antara prinsipal-agen dengan beberapa asumsi: 1) tentang manusia, yang mementingkan dirisendiri (self interest), memiliki keterbatasan rasional (bounded rationality), cenderung menghindari resiko (risk-aversion); 2) tentang organisasi, di mana ada konflik kepentingan antar anggotanya; dan 3) tentang informasi, di mana informasi adalah suatu komoditi dan dapat dibeli (Eisenhardt, 1989: 61).

Hubungan antara principal (bank) dan agent (nasabah peminjam) dalam kontrak pembiayaan mudārabah dapat diwujudkan dalam bentuk perjanjian kontrak muḍārabah yaitu perjanjian kontrak antara pemilik modal (bank/shahibu almal/principal) dengan pengusaha (nasabah peminjam/mudārib/agent). Dalam perjanjian tersebut akan disepakati rukunrukun kontrak, yaitu (Muhammad, 2006: 5): (1) pemilik modal/principal/bank syariah; (2) pelaku usaha/muḍārib/agent; (3) proyek yang akan dijalankan; (4) nisbah pembagian keuntungan dan porsi pembagian kerugian; (5) masa kontrak atau perjanjian.

Dalam kontrak muḍārabah, kepemilikan proyek adalah milik bersama antara pemodal (shahibu al-maal) dengan pelaksana usaha (muḍārib), modal mud\}arabah tetap menjadi milik shahibu almaal, adapun keuntungan yang dihasilkan oleh usaha tersebut menjadi milik bersama. Muḍārib tidak berhak mengambil bagian dari keuntungannya tanpa sepengetahuan atau kehadiran shahibu al-maal, demikian pula sebaliknya. Permasalahan yang muncul antara pihak bank (shahibu almaal) dan pengusaha (muḍārib) inilah yang disebut dengan permasalahan keagenan (agency problem). Masalah keagenan di perbankan syariah timbul karena kedua belah pihak memiliki kepentingan yang berbeda dan adanya informasi yang asimetris, sehingga pemilik modal (shahibu al-maal) tidak yakin bahwa agen akan selalu bertindak untuk kepentingan perusahaan (Muhammad, 2006: 5).

Praktik keuangan modern, menawarkan 2 cara yang bisa dilakukan guna mengurangi risiko akibat tindakan manajer yang merugikan, yaitu pemilik modal melakukan pengawasan (monitoring) dan manajer sendiri melakukan pembatasan atas tindakantindakannya (bonding) (Jensen dan Meckling: 1976). Namun, kedua mekanisme tersebut akan menimbulkan biaya pengawasan (monitoring cost) dan biaya pengikatan (bonding cost) yang menyebabkan ketidakefisienan kontrak (Ardiansyah, 2014 263).

Permasalahan agency dapat diminimalkan dengan cara tindakan pemilik dana untuk melakukan screening 
terhadap pelaku proyek dan proyek yang akan dibiayai. Bank syariah melakukan seleksi yang ketat terhadap perusahaan yang akan dibiayai dengan skema muḍārabah serta menerapkan sejumlah batasan tertentu Screening ini dilakukan dalam rangka untuk mengurangi terjadinya adverse selection. Masalah penting yang perlu dicermati pemodal (principal) dalam melakukan kontrak muḍārabah dalam memperkecil efek negatif agency problem adalah dengan mempertimbangkan adanya adverse selection pelaku usaha berikut proyek yang akan dibiayai (Muhammad, 2006: 39).

Hal lain yang perlu dicermati perbankan syariah dalam mengurangi konflik keagenan dalam kontrak pembiayaan mudārabah adalah menyangkut manajemen risiko. Manajemen risiko sebelum pembiayaan dilakukan dengan langkah penganalisaan dengan prosedur yang ketat terhadap calon nasabah dan besaran pembiayaan yang akan diberikan untuk mengurangi adverse selection. Manajemen risiko setelah realisasi pembaiayaan antara lain dalam hal penanganan pembiayaan yang jatuh tempo, pembiayaan yang tidak sesuai dengan akad, kelalaian nasabah dalam mengelola usaha, dan penyembunyian keuntungan oleh nasabah (Musolin, 2005: 14).

Untuk mengurangi kerugaian akibat penyembunyian keuntungan, perbankan syariah dapat melakukan wa'ad, yaitu kesediaan nasabah untuk memberikan bagi hasil minimal, sehingga kecurangan nasabah dapat diminamilisir (Musolin, 2005: 15). Jika pengeloaan perusahaan dilakukan dengan baik dan pelaporan laba oleh muḍārib kepada shahibu al-maal dilakukan secara transparan, maka pengoptimalan skema bagi hasil dapat dilakukan, yang pada akhirnya dapat mengurangi konflik keagenan.

Terlepas dari semua solusi yang ditawarkan untuk meminimalisir permasalahan pembiayaan muḍārabah, seharusnya kita kembali kepada dasar yang ditetapkan tentang muḍārabah dalam AlQuran. Pembiayaan muḍarabah adalah pembiayaan yang harus didasari saling kepercayaan dari pihak-pihak yang terkait. Terkadang tidak menutup kemungkinan pihak șāhibul māl memiliki prasangka yang terhadap muḍārib. Dia akan berpikiran bahwa mudārib akan melakukan tindakan yang tidak baik. Seharusnya sebagai pemberi modal, perlu untuk mnerapkan sifat khusnudzon, atau memiliki pikiran berbaik sangka kepada muḍārib. Dengan demikian kontrak pembiayaan mudārabah ini akan didasari dengan saling percaya dan tidak mementingkan keegoisan satu sama lain (QS. Shaad: 24).

Hakikat mud̄ârabah harus didasarkan pada prinsip kejujuran dan kepercayaan penuh pemodal (investor/shahibu al-maal) kepada pengelola (agen/muḍārib) atau "trust based financing", sehingga tidak ada keragu-raguan pemodal terhadap pengelola. Dalam akad muḍarabah , pemodal harus berhati-hati dalam memberikan amanah pengelolaan uang kepada mudārib. Diharapkan dia akan mempertanggungjawabkan apa yang diamanahkan kepadanya dengan sebaik baiknya (Widodo, 2014: 141).

Maharani juga mengatakan solusi untuk mengatasi pembiayaan muḍarabah yaitu dengan menggunakan cara metafora amanah (Maharani, 2008: 491). "Syari'ate organisation and accounting: the reflection of self's faith and knowlwdge", ketika individu melihat organisasi sebagai amanah maka konsekuensi paling penting adalah tujuan dan cara pencapaian tujuan 
(etika). Makna amanah itu khalifatullah fil ardh atau menyebarkan rahmat bagi seluruh alam, untuk mencapai tujuan akhir yang sangat mulia tersebut maka proses pencapaiannya memerlukan acuan atau pedoman berupa etika yang bersumber dari nilai-nilai syariah.

\section{Adverse selection}

Adverse selection yaitu jenis asimetri informasi dimana pemilik tidak dapat mengetahui apakah suatu keputusan yang diambil oleh manajer benar-benar didasarkan atas informasi yang telah diperolehnya atau terjadi kelalaian tugas (incentive to shirk) (Harison dan Harrell, 1993: 637). Adverse selection (etika pengusaha yang secara melekat tidak dapat diketahui oleh pemilik modal). Muhammad mengutip pendapat Sadr dan Iqbal yang menyebutkan bahwa "adverse selection terjadi pada kontrak utang ketika peminjam memiliki kualitas yang tidak baik atas kredit di luar batas ketentuan tingkat keuntungan tertentu (Muhammad, 2006: 39).

Untuk mengatasi adverse selection, pihak bank perlu mengetahui karakteristik mudārib. Melalui analisis atas dokumen yang diajukan muḍārib, shahibu al-maal bisa memperoleh sebagian informasi yang diperlukan untuk menilai karakteristik muḍārib (Ardiansyah: 2014: 263). Perbankan syariah yang akan memberikan pembiayaan mud̄ārabah- untuk meningkatkan screening terhadap karakteristik dari muḍ̄arib. Misalnya saja penilaian dari segi kemampuan bisnis yang mereka miliki, asal-usul mereka, dan yang terpenting sejauh mana komitmen mereka dalam menjalankan usahanya (Kurniawai, 2008: 49).

Tarsidin memberikan pendekatan lainnya yang tidak sepenuhnya mengandalkan pada verifikasi. Shahibu al- maal dapat menawarkan suatu skema bagi hasil yang lebih menguntungkan bagi muḍārib apabila ia menyatakan dengan benar karakteristiknya. Skema bagi hasil tersebut harus dapat membuat mudārib menyatakan dengan sebenarnya karakteristiknya (Tarsidin, 2010: 46).

Muḍārib akan dihadapkan pada risiko bahwa dirinya tidak memperoleh kredit pembiayaan jika menyatakan dengan benar karakteristiknya. Di samping itu, muḍārib juga dihadapkan pada kemungkinan bahwa dirinya memperoleh rasio bagi hasil yang lebih rendah jika menyatakan dengan benar karakteristiknya. Dengan demikian, pengungkapan informasi privat yang dimiliki oleh muḍārib kepada shahibu almaal hanya bisa dicapai jika skema bagi hasil tersebut incentive compatible (insentif yang diperoleh cukup) (Tarsidin, 2010: 46).

Muḍārib yang bersedia memperoleh pembiayaan dengan rasio bagi hasil yang rendah mengindikasikan bahwa karakteristiknya rendah. Sedangkan muḍārib dengan karakteristik yang tinggi tidak akan menerima kontrak bagi hasil yang menawarkan rasio bagi hasil yang rendah. Meskipun dengan rasio bagi hasil yang rendah, muḍārib tetap dapat memperoleh level utilitas tertentu yang diinginkannya, namun muḍārib dengan katakterisik tinggi tersebut memiliki banyak alternatif pembiayaan lainnya yang menawarkan rasio bagi hasil yang lebih tinggi. Hal ini menunjukkan bahwa shahibu al-maal dapat menggunakan skema bagi hasil untuk menyeleksi muḍārib dan menekan permasalahan adverse selection.

\section{Moral hazard}

Moral hazard adalah jenis asimetri informasi dalam mana satu pihak atau lebih yang melangsungkan atau akan melangsungkan suatu transaksi usaha atau transaksi usaha potensial dapat mengamati 
tindakan-tindakan mereka dalam penyelesaian transaksi-transaksi mereka sedangkan pihak-pihak lainnya tidak. Moral hazard dapat terjadi karena adanya pemisahan pemilikan dengan pengendalian yang merupakan karakteristik kebanyakan perusahaan besar.

Moral hazard atau perilaku jahat adalah tindakan pelaku ekonomi yang menimbulkan kemudaratan baik untuk diri sendiri maupun orang lain. Perilaku moral hazard dalam perbankan merupakan salah satu faktor yang mengakibatkan terjadinya pembiayaan bermasalah. Pembiayaan bermasalah atau kredit macet adalah suatu keadaan dimana nasabah sudah tidak sanggup lagi membayarkan sebagian atau seluruh kewajibannya kepada bank seperti yang telah diperjanjikannya (Kuncoro, 2003: 462).

Moral hazard adalah tidak diindahkannya masalah moral dan etika dalam berbisnis, baik dilakukan oleh pengusaha maupun mungkin juga dilakukan oleh lembaga keuangan syari'ah itu sendiri. Pengusaha sering membuat proposal tidak sesuai dengan kenyataan di lapangan proyeknya akan memberikan keuntungan tinggi dan mendorong pengusaha untuk membuat proyeksi bisnis yang terlalu optimis. Sedangkan dari lembaga keuangan syari'ah misalnya menuntut bagi hasil yang sangat tinggi tanpa mempertimbangkan keadilan bagi pengusaha (Nabawi, 2012: 58).

Moral hazard pada nasabah umumnya terjadi pada produk pembiayaan yang berbasis pada prinsip profit loss sharing (mudāarabah dan musyārakah). Akad muḍārabah yang tidak mensyaratkan jaminan dan juga memberikan hak penuh pada muḍārib untuk menjalankan usaha tanpa campur tangan shahibu al-maal dan ditanggungnya kerugian oleh shahibu al- maal (kecuali kesalahan manajemen) mengakibatkan akad pembiayaan ini sangat rentan terhadap masalah moral hazard.

Moral hazard timbul karena muḍārib menggunakan pembiayaan yang diterimanya tidak sesuai dengan yang diperjanjikan. Moral hazard merupakan penyakit yang timbul setelah akad kredit/pembiayaan ditandatangani dan dana telah disalurkan. Permasalahan moral hazard biasa terjadi pada kondisi dimana mudārib bersifat risk-averse (cenderung menghindari risiko). Ia akan lebih memilih level upaya diitingkat yang hanya sekedar memenuhi tingkat utilitas minimalnya saja. Untuk mengatasi ini, pemilik dana dapat memberikan insentif yang sesuai agar muḍārib bersedia untuk meningkatkan level upayanya.

Selain pada tingkat level upayanya yang dimana muḍa $r i b$ kurang mengerahkan upayanya, permasalahan moral hazard juga dapat berupa pelaporan jumlah profit yang tidak benar. Dalam hal ini muḍārib akan memanipulasi jumlah profit yang dihasilkannya lebih rendah daripada yang sebenarnya. Tujuan dari tindakan manipulasi ini, agar bagi hasil muḍārib kepada pemilik dana lebih rendah dari yang seharusnya dibagikan.

Menurut Chapra untuk mengurangi risiko moral hazard pada pembiayaan muḍārabah diperlukan adanya lembaga penamin simpanan. A loan guarantee scheme underwritten partly by the ghoverment and partly by the commercial banks. Demikian pula pendapat Chudhory bahwa untuk menghubungkan sektor riil dengan sektor keuangan melalui pembiayaan muḍārabah perlu adanya lembaga penjamin (Bank Indonesia: 11).

Keberadaan lembaga ini sangat menentukan kemampuan bank syariah 
dalam menggerakan sektor riil melalui alokasi pembiayaan kedaerah pedesaan, UKM dan dengan skim muḍarabah, lembaga ini yang akan melakukan investigasi mengenai perilaku mitra sehingga dapat dipercaya akan amanah dalam mengelola dana, dan memiliki kemampuan dalam berusaha. Bila perilaku amanahnya diragukan dan kemampuannya rendah tidak akan dijamin dalam memperoleh pembiayaan dari bank syariah. Untuk nasabah yang masih rendah kemampuannya lembaga dapat memberikan pelatihan sehingga nasabah yang memenuhi syarat (eligible) untuk memperoleh pembiayaan dari bank syariah dan dijamin oleh lembaga tersebut. Bank syariah akan memperoleh kembali dananya bila terjadi kegagalan nasabah karena negligence ataupun moral failure, namun bila kegagalan karena normal business loss, maka bank turut menanggung kerugian tersebut penjamin (Bank Indonesia: 11).

Sistem jaminan ini sebenarnya telah dipraktekan pada bank-bank syariah di beberapa negara. International Islamaic Bank for Invesment and Development (IIBID) dalam menjalankan pembiayaan kontrak muḍārabah menerapakan persyaratan adanya jaminan dari pihak muḍārib untuk diberilan kepada bank. Salah satu persyaratan kontak muḍārabah di Faisal Islamic Bank of Mesir (FIBE) adalah jika terbukti muḍārabah tidak memampaatkan dana atau tidak menjaga barang dagangannya sebagaimana mestinya berdasarkan ketentuana persyaratan dari investor, dimana muḍārib mengalamai kerugian, maka jaminan (garansi) yang diberikan dijadikan sebagai ganti atas kerugian yang dialaminya. Dalam kasus tersebut, muḍārib bertanggung jawab atas kerugian yang terjadi, oleh karenanya jaminan yang disyaratkan dalam kontrak menjadi konfensasi pihak bank. Jika jaminan tidak cukup, maka mudārib harus memberikan tambahan jaminan dalam jangka waktu yang di tentukan (Saeed, 2003: 103).

Penggunanan jaminan dalam pembiayaan mudāarabah telah menjadi perdebatan, berdasarkan pendapat Ulama' Klasik yang mengatakan bahwa pada dasarnya muḍārabah adalah kerjasama dengan prinsip wakalah dan amanah, jadi apabila ada shahibua al-mal menuntut adanya persyaratan jaminan (garansi) beserta ketentuan-ketentuannnya kepada pengelola (mudāarib), kontrak tersebut tidak sah. Namun dilarangnya jaminan tersebut dapat dipahami sebagai bentuk baku yang mencerminkan keadilan dalam hubungan hukum muḍarabah dalam konteks tempat dan waktu. pada kondisi zaman sekarang karena semakin tipisnya kekuatan iman dan amanah, banyak kasus penyelewengan dan penipuan (baik secara kualitas maupun kuantitas).

Fatwa dewan Syari'ah Nasional Majelis Ulama Indonesia mensyaratkan penggunaan jaminan dalam pembiayaan muḍārabah berdasarkan kaedah usul fiqh yaitu "al-maslahah al-mursalah" yang mengacu kepada kebutuhan, kepentingan, kebaikan dan maslahah umum selama tidak bertentangan dengan prinsip dan dalil tegas syari' dan benar-benar membawa kepada kebaikan bersama yang tidak berdampak menyulitkan serta merugikan orang atau pihak lain secara umum. Selanjutnya perlu ditegaskan bahwa kedudukan jaminan dalam muḍārabah adalah sebagai penjamin kepastian pelaku usaha untuk tidak menyimpang dari ketentuan-ketentuan yang ada di dalam perjanjian yang telah disepakati bersama. Jaminan menempatkan pelaku usaha untuk 
bertanggung jawab sesuai dengan kesepakatan bersama (Harahap, 2006: 54).

\section{KESIMPULAN DAN IMPLIKASI}

Sistem bagi hasil muḍārabah merupakan landasan investasi dan karakteristik umum operasional bank syariah dalam upanya menghindari praktek ribawai. Namun pada kenyataanyaa komposisi penyaluran dana kepada masyarakat lebih banyak dalam bentuk pembiayaan jual beli (murabahah) dibandingkan penyertaan modal muḍārabah. Hal tersebut diduga karena tingginya risiko yang terdapat dalam pembiayaan muḍārabah. Dari beberapa penelitian ditemukan bahwa tingginya risiko tersebut disebabkan karena adanya agency problem yang menyebabkan munculnya adverse selection dan moral hazard.

Ada beberapa hal yang yang bisa dilakukan untuk mengoptimalkan pembiayaan muḍārabah yakni melakukan screening terhadap pelaku proyek dan proyek yang akan dibiayai, melakukan analisis atas dokumen yang diajukan muḍārib, menawarkan suatu skema bagi hasil yang lebih menguntungkan bagi mudārib dan menggunakan jaminan sebagai penjamin kepastian pelaku usaha agar tidak menyimpang dari ketentuan-ketentuan yang yang telah disepakati.

Terlepas dari semua solusi yang ditawarkan seharusnya agency problem yang biasa terjadi di ekonomi konvensional tidak sepantasnya terjadi jika dikembalikan pada hakikat ekonomi Islam pada Al-Quran dan Al-Hadis. Jika pelaku-pelaku ekonomi Islam masih berprilaku seperti halnya pelaku ekonomi konvensional maka tidak heran jika banyak orang yang menganggap ekonomi Islam hanyalah lispstik belaka, dan akad-akad taransaksi perbankan syariah ibarat taranskasi konvensional yang "dijilbabi." Di sinilah sperlunya rekonstruksi produk-produk yang dikembangkan di perbankan syariah, agar tidak hanya memenuhi kepatuhan syariah (shari'ah compliance), tapi juga harus ditujukan untuk mewujudkan kemaslahatan umat.

\section{DAFTAR PUSTAKA}

Ardiansyah, Misnen. 2014. “Bayang-Bayang Teori Keagenan dalam Produk Pembiayaan Bank Syariah", Jurnal Itihad, Vol. 14. No. 2.

Ascarya dan Diana Yumanita. 2000. "Mencari Solusi Rendahnya Pembiayaan Bagi Hasil di Perbankan Syari'ah", Buletin Ekonomi Moneter dan Perbankan.

Baiq, Irfan Sauqi. 2006. Bank Syariah dan Pengembangan Sektor Riil, Jakarta: Republika.

Biro Perbankan Syariah Bank Indonesia, Kajian Awal Cetak Biru Pengembangan Perbankan Syariahh Di Indonesia, Jakarta.

Burhanudin, Harahap. 2006. "Kedudukan, Fungsi dan Problematika aminan dalam Perjanian Pembiayaan Mudarabah pada Perbankan Syariah”, Jurnal Yustisia, No. 69.

Eisenhardt, K.M. 1989. "Agency Theory: An Assessment and Review", Academic of Management Review. Vol. 14, No. 1.

Fatwa Dewan Syari'ah Nasional No: 07/DSN-MUI/IV/2000 Tentang Pembiayaan Muḍarabah.

Harrison, Paul D. dan Adrian Harrell. 1993. Impact of "Adverse Selection" on Project Evaluation Decisions, Academy of Manajement Journal, Vol.36, No.3, hl. 637

Jensen, M.C., dan W.H. Meckling. 1976. "Theory of the Firm: Managerial Behavior, Agency Costs and 
Ownership Structure," Journal of Financial Economics.

Kettel, Brian. 2008. Introducting to Islamic Banking and Finance, London:NW3 2PT.

Kuncoro, Mudrajat. 2003. Manajemen

Perbankan, Yogyakarta: BPFE.

Kurniawati. 2008. "Masalah Keagenan

(Agency Problem) Dalam Kontrak Muḍarabah Di Bank Syari'ah", Tesis

Program Pascasarjana Fakultas

Ekonomi Dan Keuangan Syari'ah Kajian Timur Tengah Dan Islam Universitas Indonesia.

Maharani, Satia Nur. 2008. "Menyibak Agency Problem Pada Kontrak Mudarabah Dan Alternatif Solusi", Jurnal Keuangan dan Perbankan Universitas Negeri Malang, Vol. 12:3.

Muhammad. 2011. Manajemen Bank Syariah, Yogyakarta: UPP STIM YKPN. Muhammad. 2006. Permasalahan Agency dalam Pembiayaan Mudharabah pada Bank Syariah di Indonesia, Disertasi Program Doktor Ilmu Ekonomi Universitas Islam Indonesia.

Musolin, Muhammad. 2005. Analisis Manajemen Risiko Pembiayaan Musyarakah, Yogyakarta: STEI

Nabawi, Imam. 2012. "Pengaruh Asymetric Information Dan Atribut Proyek Terhadap Agency Contractual Dalam Kontrak Pembiayaan Mudarabah Pada Bank Syariah Di D.I.Yogyakarta", Skripsi Fakultas Syariah Universitas Islam Negeri Sunan Kalijaga.

Prasetyo, Pamungkas Aji. 2013. "Identifikasi Faktor Yang Mempengaruhi Rendahnya Pembiayaan Bagi Hasil Perbankan Syari'ah (Studi Kasus PT. BRI Syari'ah Kantor Cabang Malang), Jurnal Ilmiah, Fakultas Ekonomi dan Bisnis Univesitas Brawijaya Malang.
Rahman, Afzalur. 1995. Doktrin Ekonomi Islam, Yogyakarta: Dana Bakti Wakaf.

Rivai, Veithzal dan Andria Permata Veithzal. 2008. Credit Managemnt Handbook: Konsep, Prosedur dan Aplikasi Panduan Praktis Mahasiswa, Bankir dan Nasabah, Jakarta:PT Raja Grafindo Persada.

Saeed, Abdullah. 2003. Bank Islam Dan Bunga Bank, Studi Kritis dan Interpretasi Kontemporer tentang Riba dan Bunga, Yogyakarta: Pustaka Pelajar.

Siddiqi, Muhammad Nejatullah. 1985. Partnership and Profit Sharing in Islamic Law, Leicester: The Islamic Foundation.

Sundjaja, Ridwan dan Inge Barlian. 2002. Manajemen Keuangan, Jakarta: Litera Lintas Media, 2002.

Tarsidin. 2010. Bagi Hasil: Konsep dan Analisi, Jakarta: Lembaga Penerbit Fakultas Ekonomi.

Widodo, Sugeng. 2014. Moda Pembiayaan Lembaga Keuangan Islam Perspektif Aplikatif. Yogyakarta: KAUKAB.

Wiroso. 2011. Produk Perbankan Syariah, Jakarta:LPFE Usakti.

Zharfan, Refaat. 2012. "Optimalisasi Skema Bagi Hasil Sebagai Solusi Permasalahan Principal-Agent Dalam Pembiayaan Mudarabah Pada PT. Bank BNI Syari'ah Cabang Makassar", Skripsi Fakultas Ekonomi Dan Bisnis Universitas Hasanuddin Makassar. 


\section{Ucapan Terima Kasih}

Dewan Redaksi serta Redaksi Pelaksana Jurnal Syarikah mengucapkan terima kasih dan penghargaan setinggi-tingginya kepada para pakar yang telah berperan sebagai mitra bebestari pada penerbitan Jurnal Syarikah Volume 3 Nomor 1 Juni Tahun 2017.

$$
\text { Dr. Nurul Huda, M.Si }
$$

Semoga kerjasama yang baik dapat terus berlangsung di masa-masa yang akan datang untuk lebih meningkatkan kualitas Jurnal Syarikah. 


\title{
PANDUAN BAGI PENULIS JURNAL SYARIKAH: JURNAL EKONOMI ISLAM
}

\author{
Pemutakhiran Juni 2017
}

\section{RUANG LINGKUP}

Jurnal Syarikah: Jurnal Ekonomi Islam mendorong pengembangkan ilmu pengetahuan dan teknologi dalam bidang Ekonomi Islam melalui penerbitan karya ilmiah berbasis hasil penelitian (orisinal).

\section{JENIS NASKAH}

Jenis naskah yang dipublikasikan adalah naskah orisinal hasil penelitian yang belum pernah dipublikasikan atau tidak sedang dalam proses publikasi oleh media publikasi lain dan terbebas dari plagiarisme. Bahasa publikasi adalah bahasa Indonesia atau bahasa Inggris. Setiap naskah yang masuk ke dewan redaksi akan menjalani proses peer-review.

Naskah hasil penelitian harus didasarkan atas data hasil penelitian orisinal yang belum dipublikasikan dan dianalisis menggunakan metode statistik. Naskah hasil penelitian yang disajikan secara deskriptif tanpa rancangan penelitian yang dikontrol oleh peneliti, naskah hasil penelitian yang hanya berupa pengulangan (replikasi) dari hasil penelitian yang telah dipublikasikan, misalnya hanya kondisi geografisnya yang berbeda, tidak akan dipertimbangkan untuk dipublikasikan. Naskah bernomor seri tidak dapat diterima, kecuali disampaikan dan disajikan pada waktu yang bersamaan.

\section{PENGIRIMAN NASKAH}

Naskah yang diajukan ditujukan ke Pimpinan Dewan Redaksi Jurnal Syarikah, melalui e-mail ke tuti.kurnia@unida.ac.id. Naskah dimaksud harus dilengkapi dengan Surat Pernyataan Orisinalitas dan Pemindahan Hak Publikasi yang ditandatangi oleh semua penulis.

\section{KONVENSI DAN KETAATASASAN}

Naskah harus ditulis dengan tema font Time New Roman 12, spasi ganda, batas tepi $2,5 \mathrm{~cm}$, halaman berukuran A4, menggunakan program microsoft office word. Naskah ditulis tidak lebih dari 7.500 kata berdasarkan urutan bagian berikut:

1) Judul (Title): JUDUL berbahasa Indonesia dan Inggris, Nama Penulis, Alamat Penulis, Penulis untuk Korespondensi, dan Judul Singkat (Running Head).

2) Tajuk Utama (main section headings): ABSTRACT, ABSTRAK, PENDAHULUAN, MATERI DAN METODE, HASIL, PEMBAHASAN, KESIMPULAN DAN IMPLIKASI, UCAPAN TERIMA KASIH, DAFTAR PUSTAKA.

3) Lampiran: Tabel, Grafik, dan Gambar.
Judul naskah harus berhuruf tebal dan kapital, ditulis pada bagian tengah dari baris tersendiri. Tajuk dan subtajuk ditulis pada baris tersendiri, mulai dari batas tepi kiri badan teks. Tajuk berhuruf tebal dan kapital. Subtajuk berhuruf tebal dan huruf kapitalnya hanya pada awal kata. Jarak antara tajuk dan subtajuk adalah 10 point (pt) sedangkan jarak antara tajuk atau subtajuk dan badan teks adalah 6 pt. Pembeda paragraf dimulai pada paragraf kedua setelah tajuk atau subtajuk dan dicirikan oleh baris pertamanya yang berjarak $0,5 \mathrm{~cm}$ dari batas tepi kiri badan teks.

Naskah yang terlalu panjang atau terlalu pendek akan dikembalikan kepada penulis. Sebagai pedoman, 7.500 kata setara dengan 34 halaman ukuran A4, yang ditulis dengan tema font Time New Roman 12, spasi ganda, marjin $2,5 \mathrm{~cm}$ dari semua tepi halaman. Judul tidak lebih dari 12 kata, Judul Singkat tidak lebih dari 50 karakter, Abstract dan Abstrak masing-masing tidak lebih dari 250 kata, key words dan kata kunci masing-masing 5 kata, dan Pendahuluan tidak lebih dari 500 kata.

\section{Judul}

Judul harus ringkas dan padat informasi, tidak memuat kata singkatan, dan memuat hal-hal berikut:

a) membangkitkan minat bagi pembaca yang memindai jurnal atau daftar judul jurnal.

b) Menyediakan informasi yang cukup bagi pembaca untuk menilai relevansi suatu naskah dengan minatnya

c) Memasukkan kata kunci atau frasa yang dapat digunakan dalam mengindeks dan menarik informasi tentang penelitian yang dilakukan.

d) Menghindari kata-kata yang tidak penting, seperti "suatu studi kasus ...." atau "suatu tinjauan empiris tentang ....". Hal-hal tersebut lebih tepat ditulis pada subbagian Materi dan Metode.

e) Tidak boleh memuat kata tempat, seperti “.... di Bogor"

\section{Nama dan Alamat Penulis}

Nama dan alamat penulis harus disajikan seperti contoh berikut:

G. PraditinKa ${ }^{1, a}$ dan W. munawar ${ }^{2}$

${ }^{1}$ Lembaga Penelitian dan Pengembangan Universitas Djuanda, Jl. Tol Ciawi Kotak Pos 35 Bogor 16720.

${ }^{2}$ Program Studi Ekonomi Islam Fakultas Ekonomi Islam Universitas Djuanda, Jl. Tol Ciawi No. 1 Kotak Pos 35 Bogor 16720.

aKorespondensi: Tuti Kurnia. Telepon: 0818106472; E-mail: tuti.kurnia@unida.ac.id 


\section{Judul Singkat (running head)}

Penulis harus menuliskan judul singkat tidak lebih dari 50 karakter termasuk ketukan kosong.

\section{Abstract dan Abstrak}

Abstract ditulis dalam bahasa Inggris baku secara konsisten (American English atau British English). Abstrak ditulis dalam bahasa Indonesia yang baik dan benar, menggunakan kata-kata baku. Baik abstract maupun abstrak dibuat dalam satu paragraf utuh tanpa ada acuan pustaka atau perujuk tabel dan/atau gambar, tidak lebih dari 250 kata. Isinya harus memuat masalah penting yang akan dipecahkan, tujuan, metode, hasil, kesimpulan, dan tidak boleh terlalu padat dengan angka-angka. Penyingkatan kata tidak diperkenankan kecuali kata dimaksud akan digunakan lebih dari satu kali..

\section{Keywords dan Kata Kunci}

Keywords (berbahasa Ingris) dan Kata kunci (berbahasa Indonesia), masing-masing tidak lebih dari lima kata dan sebaiknya tidak sama dengan kata-kata yang terdapat dalam judul naskah. Jika tidak memadai, dewan redaksi akan mengubahnya atas persetujuan penulis.

\section{Pendahuluan}

Pendahuluan yang ditulis tidak lebih dari 500 kata, harus menjelaskan isu-isu mutakhir yang mengarah pada pentingnya penelitian yang dilakukan, tujuan penelitian dinyatakan dengan jelas, dan menuliskan state of the art dari topik penelitiannya sehingga gambaran utama penelitiannya menjadi jelas bagi para pembaca. Namun, acuan pustaka dalam pendahuluan harus dibatasi karena bukan merupakan pembahasan awal.

\section{Materi dan Metode}

Materi dan metode penelitian harus dijelaskan secara terperinci pada bagian ini sehingga memungkinkan bagi peneliti lain untuk mengulang penelitian ini. Materi atau bahan yang digunakan tidak diperinci secara terpisah, melainkan harus terintegrasi dengan prosedur penelitian. Misalnya, .."responden diminta mengisi daftar pertanyaan menggunakan pensil 2B dan memilih satu dari tiga poster yang diperlihatkan oleh peneliti...", tidak perlu memerincinya seperti berikut: " Materi penelitian terdiri atas: daftar pertanyaan, pensil 2B, dan poster. Jika penelitian menggunakan produk berpemilik (seperti paten) untuk pembanding, produk dimaksud harus dituliskan dalam nama yang baku atau dituliskan merk dagangnya di dalam tanda kurung jika dianggap membantu memperjelas pemahaman pembaca, namun syaratnya harus mendapat izin tertulis dari pemilik produk dimaksud sebelum dipublikasikan. Model, tipe, merk, dan produsen peralatan yang digunakan dalam penelitian harus dijelaskan. Metode dan model analisis statistik harus jelas sehingga memungkinkan bagi peneliti lain untuk melakukan pengulangan.

Sistematika penulisannya diurutkan sebagai berikut: materi, rancangan percobaan dan perlakuan, prosedur pelaksanaan penelitian, analisis laboratorium, dan analisis statistik. Sistematika ini tidak kaku, dapat disesuaikan dengan ciri bidang keilmuan. Misalnya, untuk penelitian agribisnis yang tidak ada analisis laboratoriumnya, tidak perlu ada analisis laboratorium. Sebaliknya, subbagian lainnya dapat ditambahkan sesuai kebutuhan.

\section{Hasil dan Pembahasan}

Hasil penelitian, termasuk hasil analisis statistiknya dipaparkan secara terperinci dalam bagian ini. Ilustrasi, jika diperlukan dapat disajikan dalam bentuk tabel dan/atau gambar. Tabel dan gambar harus sederhana, informatif, mudah dipahami, dan mandiri, dalam arti tabel atau gambar dimaksud harus bisa menjelaskan kepada pembaca sehingga pembaca tidak harus membaca tulisannya untuk memahaminya. Hal yang sudah dijelaskan dalam tabel atau gambar tidak perlu diulang dalam tulisan. Tabel dan gambar dimuat pada halaman terpisah darik teks.

Hasil penelitian selanjutnya dibahas dengan cara membandingkannya dengan hasil penelitian pada topik serupa dari peneliti sebelumnya untuk mengungkap keajegannya (konsistensinya) apakah konsisten (sama) atau berbeda, lalu jelaskan alasan ilmiahnya atas hasil dimaksud secara lugas dan tuntas sehingga memperjelas posisi hasil penelitiannya. Selanjutnya, temuan hasil penelitian diungkapkan disertai kelebihan dan kelemahannya, jika ada. Ungkapan temuan hasil penelitian ini akan mempermudah dalam menyimpulkan hasil penelitian.

Data rataan perlakuan harus ditulis dengan galat bakunya (standard errors). Tingkat signifikansi statistik dapat dinyatakan dalam $\mathrm{P}<0,05, \mathrm{P}<0,01$, dan $\mathrm{P}<0,001$. Khusus pada tabel, tingkat signifikansi dimaksud, berturut-turut dapat ditulis dengan *, **, dan ${ }^{* * *}$ sedangkan pada tabel dan grafik, perbedaan antarperlakuan dapat ditunjukkan dengan huruf $a, b$ untuk $\mathrm{P}<0,05$ dan $\mathrm{A}$, B untuk $\mathrm{P}<0,01$.

\section{Kesimpulan dan Implikasi}

Kesimpulan memuat temuan hasil penelitian yang mencerminkan kebaruan, keorisinilan, kepioneran, keuniversalan, dan kontribusi ilmiah dalam pengembangan ilmu pengetahuan dan teknologi. Pernyataan dalam simpulan terbebas dari frasa atau istilah statistik, seperti " ..berpengaruh nyata $(\mathrm{P}<0,05) "$

Penulis harus menjelaskan implikasi hasil penelitiannya dalam pengembangan keilmuan, dan dampaknya terhadap lingkungan, sosial, budaya, 
ekonomi, politik, dan/atau hukum. Implikasi dipaparkan dalam bahasa yang sederhana agar pembaca noncendekia dapat memahaminya dengan mudah.

\section{Ucapan Terima Kasih}

Ucapan terima kasih hanya wajib ditulis jika penelitian didukung (biaya, sarana, tenaga) oleh instansi atau individu, atau penelaah sejawat jika naskahnya ditelaah sebelum dipublikasikan.

\section{Daftar Pustaka}

Penulis bertanggung jawab atas kebenaran semua sumber pustaka yang dirujuk dan dituliskan dalam Daftar Pustaka dan yang diacu dalam teks. Sumber pustaka sangat dianjurkan menggunakan terbitan terbaru (10 tahun terakhir), dan disajikan secara alfabet dan dituliskan menurut format nama tahun. Beberapa format dan contoh penulisannya antara lain:

Naskah jurnal atau abstrak. Format: Nama Penulis. Tahun. Judul. Nama Jurnal. Volume: Halaman. Contoh:

Rahmawati R, G Praditina dan RA Munjin. 2009. Model pelayanan rumah sakit berbasis karakteristik sosial ekonomi masyarakat untuk meningkatkan kepuasan pasien. Jurnal Humaniora. 1(1): 18-29.

Buku. Format: Nama Penulis atau Nama Editor atau Nama Lembaga. Tahun. Judul. Edisi, Nama Penerbit, Tempat Penerbitan. Contoh:

Roestamy M. 2011. Konsep-konsep hukum kepemilikan properti bagi asing (dihubungkan dengan hukum pertanahan). Edisi pertama. PT. Alumni. Bandung.

Bab buku atau proseding. Format: Nama Penulis. Tahun. Judul. Dalam: Judul buku atau proseding (Nama Editor). Volume: Halaman. Nama Penerbit, Tempat Penerbitan. Contoh:

Goulet D. 2000. Ethics, culture and development: livestock, poverty and quality of rural life. In: Livestock, ethics and quality of life (eds. Hodges, John and Han, In K). 131-154. CABI Publishing, New York, NY 10016, USA.

Laporan pada pertemuan ilmiah (konferensi, workshop, dll) yang tidak tercakup dalam buku atau proseding. Format: Nama Penulis. Tahun. Judul. Judul atau Nama Pertemuan Ilmiah, Tempat Pertemuan. Jumlah halaman. Contoh:

Jalal F. 2011. Tantangan dan peluang pendidikan di Indonesia. Orasi Ilmiah. Wisuda XXVI Sarjana dan Pascasarjana Universitas Djuanda, Bogor. 16 hal.

Tesis atau Disertasi. Format: Nama Penulis. Tahun. Judul. Tesis atau Disertasi. Nama Perguruan Tinggi, Tempat Perguruan Tinggi. Contoh:

Roestamy M. 2008. Kepastian hukum atas kepemilikan rumah dan bangunan gedung oleh investor asing dikaitkan dengan asas nasionalitas dalam sistem hukum pertanahan Indonesia. Disertasi. Program Studi Doktor Ilmu Hukum Fakultas Hukum Universitas Padjadjaran, Bandung.

Karya Ilmiah Lepas yang dimuat pada Website. Karya ilmiah lepas yang dimuat pada website hanya dapat digunakan jika literatur standard lainnya tidak tersedia. Format: Nama Penulis. Tahun. Judul. Diunduh tanggal-bulan-tahun dari http://.... Contoh:

Bryant P. 1999. Biodiversity and Conservation. Retrieved October 4, 1999 from http://darwin bio.uci.edu/ sustain/bio65/Titlpage.htm

\section{Penulisan Nama Penulis yang Diacu pada Teks}

Nama penulis yang diacu di dalam teks tidak diperkenankan menggunakan footnote. Jika jumlah penulis kurang dari tiga nama penulis ditulis semua, jika jumlah penulis tidak kurang dari tiga, hanya penulis utama yang ditulis dan diikuti dengan et al. Contoh: Syamsah (2010) menyimpulkan bahwa pajak dan zakat memiliki hubungan reduktif dan deduktabel. Parameter kualitas layanan puskesmas secara simultan mempengaruhi kepuasan pasien (Yuningsih dan Maulana 2010). Kekurangan dari kualitas pelayanan rumah sakit dapat diatasi apabila rumah sakit memperhatikan karakteristik pasien (Rahmawati et al. 2010). Tingkat kepuasan pasien menjadi indikator penting dalam mengukur kualitas pelayanan kesehatan (Yuningsih dan Maulana 2010; Rahmawati et al. 2010).

\section{Tabel}

Tabel harus dibuat sesederhana dan sesedikit mungkin, namun sekurang-kurangnya harus memuat dua baris data. Jika hanya ada satu baris data, maka penyajiannya harus menggunakan grafik. Garis horisontal tabel hanya boleh untuk mencirikan batas baris teratas (heading) dan garis terbawah dari badan tabel, sedangkan garis-garis kolom tabel tidak diperkenankan. Tabel dibuat dengan menggunakan fungsi tabel dalam program microsoft office word. Judul tabel harus ringkas, jelas, dan informatif, diberi nomor urut angka arab, huruf kapital hanya pada huruf pertama judul tabel kecuali beberapa nama diri, dan ditempatkan di atas badan tabel. Lazimnya, peubah disajikan dalam baris dan perlakuan disajikan pada kolom tabel. Keterangan tabel disajikan di bagian bawah badan tabel tanpa menuliskan kata keterangan. Di dalam teks, nomor tabel harus dirujuk, misalnya: kepribadian dalam pandangan Islam merupakan integrasi sistem kalbu, akal, dan nafsu (Tabel 1). Judul tabel, tabel dan keterangan tabel disajikan pada halaman tersendiri setelah Daftar Pustaka. Lebar tabel $80 \mathrm{~mm}$ atau $160 \mathrm{~mm}$. Jangan menyisipkan tabel pada bagian teks. Contoh Tabel lebar $80 \mathrm{~mm}$ : 
Table 1 Persentase distribusi daya fitrah nafsani dalam pembentukan kepribadian

\begin{tabular}{lccc}
\hline \multirow{2}{*}{$\begin{array}{l}\text { Daya fitrah } \\
\text { nafsani }\end{array}$} & \multicolumn{3}{c}{ Tingkat kepribadian (\%) } \\
\cline { 2 - 4 } & Muthmainnah & Lawwamah & Ammarah \\
\hline Kalbu & 55 & 30 & 15 \\
Akal & 30 & 40 & 30 \\
Nafsu & 15 & 30 & 55 \\
\hline
\end{tabular}

Format tabel diubahsuai dari Sulaiman H (2010) tanpa mengubah substansi.

\section{Gambar dan Grafik}

Gambar dan grafik dibuat dalam format JPEG dan hanya diperbolehkan jika data hasil penelitian tidak dapat disajikan dalam bentuk tabel. Grafik yang dibuat dengan program microsoft office excel harus diubahsuiakan menjadi format JPEG dengan kualitas gambar yang layak cetak. Ukuran lebar gambar adalah $80 \mathrm{~mm}$ atau $160 \mathrm{~mm}$. Judul gambar harus ringkas, jelas, dan informatif, diberi nomor urut angka arab, huruf kapital hanya pada huruf pertama judul gambar kecuali beberapa nama diri, dan ditempatkan di bagian bawah gambar. Contoh gambar berformat JPEG lebar $80 \mathrm{~mm}$ (Gambar 1).

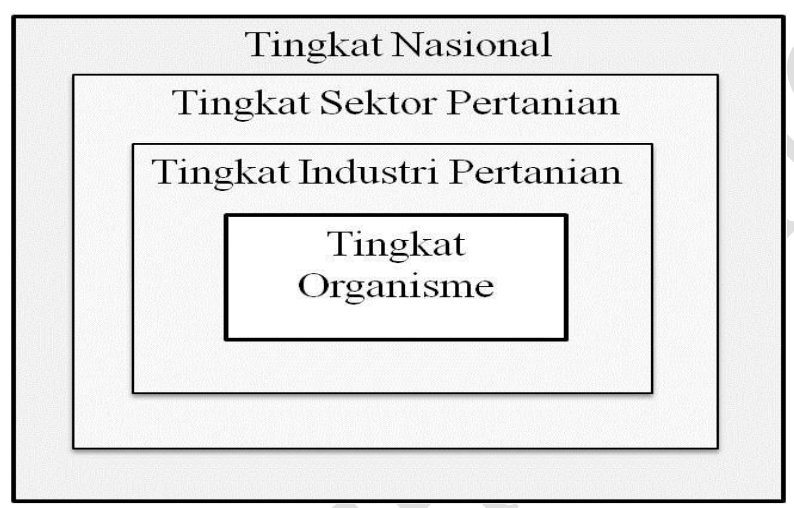

Gambar 1 Empat tingkat domain untuk menghadapi agroterorisme (ubahsuai dari Kohnen 2000).
Keterangan gambar ditulis setelah dan merupakan bagian integral dari judul gambar. Gambar dan judul gambar disajikan pada halaman tersendiri setelah halaman tabel. Di dalam teks, seluruh nomor gambar harus dirujuk secara berurutan seperti nomor tabel. Gambar dicetak hitam putih dan jika penulis menghendaki gambar berwarna, maka biaya pencetakan menjadi tanggung jawab penulis.

\section{Cetak Lepas}

Penulis yang naskahnya telah dipublikasikan akan mendapatkan satu Jurnal Humaniora dan dua eksemplar cetak lepas (reprint) artikelnya. Penulis yang ingin menambah jumlah jurnal dan cetak lepasnya dapat memesannya ke Dewan Redaksi melalui telefon atau email. Berikut ini adalah daftar harga Jurnal Humaniora dan cetak lepasnya, belum termasuk ongkos kirim.

Daftar harga Jurnal Humaniora dan cetak lepasnya

\begin{tabular}{lll}
\hline Jumlah & $\begin{array}{l}\text { Jurnal Syarikah } \\
\text { (Rp/eksemplar) }\end{array}$ & $\begin{array}{l}\text { Cetak lepasnya*) } \\
\text { (Rp/eksemplar) }\end{array}$ \\
\hline $1-5$ & 75.000 & 30.000 \\
6 atau lebih & 60.000 & 25.000 \\
\hline
\end{tabular}

${ }^{*}{ }^{6}$ pemesanan minimal 5 eksemplar. 


\section{SURAT PERNYATAAN ORISINALITAS ${ }^{1}$}

Kepada

\section{Dewan Editor Jurnal Syarikah}

Program Studi Ekonomi Islam Fakultas Ekonomi islam

Universitas Djuanda Bogor

Bersama ini kami mengajukan naskah,

\section{Judul :}

Penulis:

\begin{tabular}{|c|c|c|c|c|}
\hline No & $\begin{array}{c}\text { Penulis lengkap dengan } \\
\text { gelar akademik }\end{array}$ & Nama dan Alamat Institusi, email & $\begin{array}{l}\text { Tanda } \\
\text { Tangan }\end{array}$ & Tanggal \\
\hline
\end{tabular}

1

2

3

untuk dipublikasikan pada Jurnal Syarikah. Kami menyatakan bahwa naskah dimaksud adalah naskah orisinal hasil penelitian kami yang belum pernah dipublikasikan, tidak sedang dalam proses publikasi oleh media publikasi lainnya, tidak akan diajukan ke media publikasi lainnya selama dalam proses penelaahan (review) kecuali jika kami menarik secara resmi naskah dimaksud dari Dewan Redaksi Jurnal Syarikah, terbebas dari plagiarisme, dan kami bertanggung jawab atas seluruh substansi naskah berjudul tersebut di atas yang kami tulis.

Nama penulis untuk korespondensi:

Telepon/(hanya digunakan untuk keperluan korespondensi)

Email: (untuk keperluan korespondensi dan akan dicantumkan pada artikel yang

dipublikasikan)

Terima kasih atas perhatian dan kerjasamanya.

Tanggal:

Penulis:

Tanda tangan:

\footnotetext{
${ }^{1}$ Dikirim ke Dewan Redaksi Jurnal Syarikah, Program Studi Ekonomi Islam Fakultas Ekonomi Islam Universitas Djuanda Bogor, Gedung B Lantai IV Jl Tol Ciawi No. 1 Kotak Pos 35 Ciawi Bogor 16720, difaksimilikan ke 02518240985, dan hasil scanning-nya diemailkan ke Jurnal.Syarikah@unida.ac.id.
} 


\section{SURAT PERNYATAAN PEMINDAHAN HAK CIPTA ${ }^{2}$}

Yang bertanda tangan di bawah ini adalah penulis naskah yang berjudul:

yang diajukan untuk dipublikasikan pada Jurnal Syarikah: Jurnal Ekonomi Islam ISSN 2442-4420 menyatakan bahwa:

Kami bersedia memindahkan hak publikasi, distribusi, reproduksi, dan menjual naskah kamiyang berjudul tersebut di atas sebagai bagian dari Jurnal Syarikah kepada Dewan Redaksi Jurnal Syarikah ISSN 2442-4420

Demikian surat pernyataan ini saya buat dengan sadar, penuh rasa tanggung jawab, dan tanpa paksaan dari pihak mana pun!

\begin{tabular}{llcc}
\hline No & $\begin{array}{l}\text { Nama Penulis (lengkap } \\
\text { dengan gelar akademik) }\end{array}$
\end{tabular}$\quad$ Nama dan Alamat Institusi, email $\begin{gathered}\text { Tanda } \\
\text { Tangan }\end{gathered}$ Tanggal




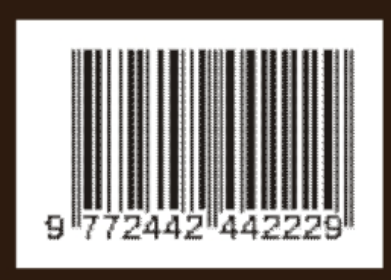

